\title{
Sola Fides at the Core of Varieties: Luther as Religious Genius in William James's Thought
}

\author{
CLAUDIO MARCELO VIALE \\ IDH-CONICET Universidad Nacional de Córdoba (Argentina) \\ Universidad Nacional de La Rioja (Argentina) \\ Indeed, that man Luther is the master of us all. \\ -Søren Kierkegaard ${ }^{1}$
}

\section{Introduction}

Classical American pragmatism is an estimable source to understand religion as an inescapable human endeavor. Despite logical divergences among the approaches of classical figures, they share a primeval interest in religion. Charles Sanders Peirce, for example, gave religion a central role in his philosophy, especially through his conception of evolutionary love; Josiah Royce linked religion and morality in an attempt to assert the vitality of the idealist tradition. Finally, John Dewey fought "militant atheism" through a vision that could be called religious naturalism. As part of the core of this movement, William James's philosophy has religion as a fundamental issue too.

Numerous books and articles have already been written on James's views on religious experiences and religion. Thus, it is not my purpose to repeat or rephrase either James or the literature, but to explore a couple of neglected connections: the line that can be drawn between Luther and James, on the one hand; and on the other hand, the role that Hegel's conception of religion could play in relation to Luther and James. Accordingly, I will support the view that inwardness is one of the foremost ways to understand the links between these thinkers.

Given this general framework, one of the main issues relates to institutional creeds, particularly to the role of the Protestant spirit and denominations in classical American philosophy. As regards James, he tends to oscillate between identifying his writings as belonging to the general spirit of Protestantism, on

THE PLURALIST Volume io, Number I Spring 20I5: pp. 80-Io6

80

(C) 2015 by the Board of Trustees of the University of Illinois 
the one hand, and as referring to religious experiences beyond the Protestant framework, on the other. ${ }^{2}$ The first tendency clearly appears in several parts of James's work. ${ }^{3}$ The literature has also reflected this dualistic viewpoint. David Hollinger, for example, points out that James unequivocally belongs to the Protestant tradition. ${ }^{4}$ Meanwhile, the second tendency can be found in James's definition of religion at the beginning of The Varieties of Religious Experience:

Religion, therefore, as I now ask you arbitrarily to take it, shall mean for us the feelings, acts, and experiences of individual men in their solitude, so far as they apprehend themselves to stand in relation to whatever they may consider the divine. (34; emphasis in original)

Some outstanding interpreters of James's work, such as Ralph Barton Perry and Henry Levinson, emphasize that these kinds of statements grasp the core of the Jamesian point of view on religion. ${ }^{5}$ Consequently, in the circumscription of this topic, James would ground his conception of religion in the psychology of religious experiences and not in a particular theology, doctrine, or sectarian view.

My position in this paper, despite this Jamesian circumscription of the topic, is that there are several Protestant issues within James's works, and especially in Varieties. ${ }^{6}$ Those aspects seem to refer mainly to Calvinism (in their different versions), which appears to be the skeleton of Varieties (see Hollinger; Levinson 15). Besides, Calvinism could be interpreted as a biographical source of James's religious tendencies. As Gerald Myers writes:

Biographers have conjectured about the source of James's [religious] need. It may have resulted from the strict Presbyterianism of his powerful and wealthy grandfather, the elder William James, or from his father's rebellious, freethinking bouts with Calvinism, other influences may have been the piety of his mother, his early reading of Jonathan Edwards, and his study of the Great Awakening in American history. (256)

From Myers's words, we could infer that, despite the numerous sources used in Varieties, only the Protestant ones are essential to understand James's religious outlook. Meanwhile, within the literature, some authors relate James to the two fundamental branches of Protestantism: Calvinism and Lutheranism. Amanda Porterfield, for instance, refers to the dual Protestant character in James's viewpoint: Luther's conception of faith as an essential feature of religion, on the one hand, and Calvin's idea of moral strenuousness empowering religious believers, on the other (147).

Besides Porterfield, three authors - to the best of my knowledge-have stressed the relevance of Luther's influence in James's religious thought. One 
of them was David Zehnder, who relates James to Lutheran Reformation (301). He points out one aspect of James's conception of religion (i.e., selfsurrender), which will be widely referred to in the corpus of this paper. ${ }^{7}$ Meanwhile, William Spohn wrote an insightful interpretation of James's religious thought:

A particular narrative of Christianity had already determined the shape of redemption that he assumed to be nonsectarian. He [James] extrapolated a common pattern from his sources, but they were mostly Protestant and almost exclusively Christian. In the Varieties he relied heavily on the conversions studied by Edwin Diller Starbuck. They were taken primarily from Western sources and interpreted through conventional theological frameworks, particularly the paradigm of justification through faith articulated by Reformation Christianity. Martin Luther defined Christian conversion according to Augustine's reading of Paul's conversion experience. Romans and Galatians in effect are interpreted through the story of Augustine's Confessions. (32) ${ }^{8}$

Spohn clearly remarks upon something that is essential to the interpretation I present in this article: at the core of Varieties, there is a particularly Protestant-more specifically, Lutheran — way to understand religious experience. The third author who relates James with Luther was Paul Hinlicky. He offers a sharp interpretation of Luther's dual influence on James's thought: Luther's conception of religion should be considered, on the one hand, as belonging to the healthy mentality, especially through his doctrine of justification by faith; and on the other hand, it should also be interpreted as exemplifying the religion of sick souls. But how can this duality be explained? Hinlicky points to Luther's view of "enthusiasm" as the most relevant element in religion (Hinlicky 25), as the key to the understanding of this duality. Beyond creeds and rites, there exists an inescapable fundamental closeness in the relationship between the individual and God. In my interpretation of Hinlicky, Luther's conception of religion would be for James either the relationship of enthusiastic hope of the healthy mentality, (the ecstatic selfsurrender) or the trembling despair of sick souls. ${ }^{9}$ I think that this is one of the reasons why Luther is the paradigmatic model of religious genius in Varieties. I will return to this issue in the corpus of the article. Summing up, there seems to be at least four approaches to understanding James's thought on religion: in the first place, interpreters who point out the nonsectarian and non-institutional character of James's religious conception as its more important aspect (e.g., James's circumscription of the topic and conclusion in 
Varieties; Perry; Levinson; see also note 5); secondly, authors who think that James's conception of religion should be understood as a form of inherited and diluted Calvinism, which belongs to the liberal Protestant tradition and emphasizes the moral strenuousness that religion gives us (especially Porterfield; Hollinger); thirdly, those who appeal to the influence of Swedenborg's heterodox theology through the writings and influence of Henry James, Sr. (Croce; Habegger); and finally, authors who think that one of the most important sources to understand James's religious thought is Martin Luther's Protestantism (Zehnder; Spohn).

My article clearly belongs to the fourth interpretative approach. I attempt to focus on one aspect of James's thought, namely its link with Luther and Lutheranism, which is examined from both a narrow and a comprehensive perspective. The former refers to the role played by Luther's conceptions of religion within James's work-specifically in Varieties. The latter deals with Luther's thought and the development of Lutheranism from its origin, and the role that James's conception could play in connection with it.

Grounded on those perspectives, I defend three hypotheses in this work: first, that James's conception of religion is markedly influenced by Luther's thought in central parts of Varieties; second, that the Lutheran core of James's view lies in the split he makes between religion and morality, on the one hand, and in the distinction between the content of faith and having faith, on the other hand; third, that James's conception of religion is one of the most radical representatives of a philosophical way to interpret Luther's thought: the primacy of Luther's conception of faith against Luther's idea of Church and sola scriptura- a comprehensive perspective integrating James's Varieties into the philosophical reception of Lutheranism. ${ }^{10}$

\section{Luther and Lutheranism}

It is well known that at the turn of the sixteenth century, Martin Luther triggered a schismatic religious revolution that undermined Catholic hegemony, changing religion in the world forever. I will briefly examine some aspects of this complex phenomenon, that is, Reformation in its Lutheran vein, which are relevant to dealing with James's conception of religion: (1) Luther's idea of grace, (2) Luther's conceptions of justification by faith alone/justification by works, (3) Luther's idea of salvation, (4) Luther's idea of sola scriptura, and (5) Luther's concept of church. From my perspective, these notions represent the core of Luther's religious thought. 
The first three conceptions are closely connected. Luther's idea of grace turns around God's mercy as a gift conferred on human beings independently of their works. Luther paradigmatically sustains this position in the following paragraph of The Good Works:

Look here! This is how you must cultivate Christ in yourself, and see how in him God holds before you his mercy and offers it to you without any prior merits of your own. It is from such a view of his grace that you must draw faith and confidence in the forgiveness of all your sins. Faith, therefore, does not originate in works; neither do works create faith, but faith must spring up and flow from the blood and wounds and death of Christ. (38; emphasis added)

Furthermore, Luther maintains that we do not deserve this gift from God. So, as Alister McGrath writes: "[G] race is the 'undeserved and unmerited divine favour towards humanity" (88). This is, as McGrath argues, a fundamental issue:

It is the idea of grace as the unmerited favour of God which underlies the doctrine of justification by faith, generally and rightly regarded as underlying the origins of the Lutheran Reformation in Germany. (89

It is well known that the target of Luther's attack was the sale of indulgences. An indulgence was a document that assured its possessor a remission of sins for himself or for a soul in Purgatory. First, Luther rebelled against the excess of indulgence sellers (mainly in 95 Theses). In subsequent books, however, Luther opposes the very idea of indulgences and questions the authority of the Catholic Church to sell or give indulgences (particularly in The Babylonian Captivity of the Church). By attacking indulgences and the authority of the Catholic Church, Luther insists on the idea that to be justified before God does not entail any good work on our part but only our belief in Him and His word. Thus, what matters is not our merits before a righteous God, but our faith.

Grace and faith are related issues in Luther's thought. While grace is a divine gift for humanity, it needs to be accepted by human beings. Such acceptance is what we call faith, which entails self-negation to give place to Christ:

Now if God is to live and to work in him, all this vice and wickedness must be choked and uprooted, so that in this event there is rest from of all our works, thoughts and life, so that henceforth (as St. Paul says in Galatians 2:20) it is no longer we who live, but Christ who lives, works and speaks in us. (Luther, Good Works 28) 
This is a crucial issue regarding James's conception of religion since it entails "relaxation" or "quietism" and not "action" as a central common topic between James and Luther. Then, it is from the combination of grace and faith that the idea of salvation emerges, that is, our salvation-the third aspect of Luther's thought that I mention-depends on both the undeserved grace that God confers on us and our acceptance of such grace, that is, our faith in God and His word.

The fourth and fifth issues focus on objective aspects of Luther's thought. The former relates to the doctrine of sola scriptura. As it is well known, Luther attacked the authority of the Catholic Church and its system based on seven sacraments by simplifying it. For him, there were only two sacraments: baptism and communion. Such a simplification was based on the idea that the Holy Bible is the only authoritative source and that rituals added through different temporal processes are not important. Thesis 62 is an example of this conception: "The true treasure of the church is the most holy gospel of the glory and the grace of God" (Luther, 95 Theses 13).

The last issue that I will refer to is Luther's idea of Church, which is one of the most complex concepts within his thought. The question that arises is what the nature of a church is. Luther faced two options: either to sustain that there exists a visible church connected with the apostolic past-which poses the problem of differentiating such a church from the Catholic Church-on the one hand, or to hold that actual church is only in Heaven, on the other hand-which brings the problem of differentiating between such a church and the radical wing of Protestantism. Underlying the problem of the nature of the church is the relationship between the church and the Bible. Put differently, why do we need a church if we have the Bible? I will refer to these features below.

It has often been said that Luther's thought entails paradoxical claims. Features (1)-(3) mentioned above, for example, mainly refer to one aspect of Luther's thought, namely the foundation of religion in individual consciousness through the appeal to grace and faith. On the other hand, features (4)-(5) make reference to another aspect of Luther's thought, which is its foundation in the objective source of the Bible and the church. Put differently, (1)-(3) refer mainly to inward conviction as the source par excellence of religion, while (4)-(5) focus on sources that are independent of individuals. How can Luther's thought be understood in this context?

One option is to distinguish between the young and the mature Luther, as Gerhard Ebeling and Ginzo Fernández, among others, did. ${ }^{11}$ While the young Luther is mainly associated with the 95 Theses of Wittenberg (and 
the books and pamphlets written until 1525) and regarded as a champion of the liberty of consciousness, the mature Luther is seen as the originator of a new orthodoxy. A clear example of young Luther's conceptions can be found in To the Christian Nobility of the German Nation:

Besides, if we are all priests, as we said above, and all have one faith, one gospel, one sacrament, why should we not also have the power to test and judge what is right or wrong in matters of faith? What becomes of Paul's words in I Corinthians 2:15: "A spiritual man judges all things, yet he is judged by no one"; and II Corinthians 4:13: "we all have one spirit of faith." Why, then, should not we perceive what is consistent with faith and what is not, just as well as an unbelieving pope does?" (135)

Despite the medieval framework of Luther's thought, he has written paragraphs like this, where a new idea of liberty is at stake. This is the kind of source that philosophical receptions of Luther — particularly Hegel—refer to. In other words, the philosophical course of Lutheranism relates mainly to subjectivism as its central feature, which considers our experience of God to be the fundamental aspect of religion to the extent that we are guided by the spirit. ${ }^{12}$

Meanwhile, an example of the second position can be found in Luther's Catechism. There, he insists that plain people should learn not through scriptures but through some simple means such as the Creed:

In the first place let the preacher above all be careful to avoid many kinds of or various texts and forms of the Ten Commandments, the Lord's Prayer, the Creed, the Sacraments, etc., but choose one form to which he adheres, and which he inculcates all the time, year after year. For [I give this advice, however, because I know that] young and simple people must be taught by uniform, settled texts and forms, otherwise they easily become confused when the teacher to-day teaches them thus, and in a year some other way, as if he wished to make improvements, and thus all effort and labor [which has been expended in teaching] is lost.

Also our blessed fathers understood this well; for they all used the same form of the Lord's Prayer, the Creed, and the Ten Commandments. Therefore we, too, should [imitate their diligence and be at pains to] teach the young and simple people these parts in such a way as not to change a syllable, or set them forth and repeat them one year differently than in another [no matter how often we teach the Catechism]. (Luther, Small Catechism 313)

To put it differently, Luther's conception of religion can be interpreted as being divided into two veins: subjectivist and objectivist. In the former, 
the sola fides principle tends to prevail, while in the latter, the sola scriptura principle — or, paradoxically, the authority of the Lutheran Church-is the prevailing one. While philosophical views tend to emphasize the subjectivist aspect of Luther's thought, theological orthodoxy relies on the principle of sola scriptura, minimizing the scope of the principle of sola fides. Thus, Luther's duality explains the diverse receptions of his work: from the Biblicism of the theological orthodoxy of the sixteenth century through the seventeenth century to the philosophical recreations of Schleiermacher, Hegel, and Schopenhauer.

This is a fundamental issue regarding the reception of Luther's thought. For philosophical receptions of Luther (particularly Hegel's), the fundamental aspect is represented by the principle of sola fides (and the individual's liberty for individuals that this entails), but they have the problem to integrate this principle with the "objectivist" dimension of Luther's thought: the conceptions of sola scriptura and of church. Meanwhile, the theological receptions of Luther have the opposite problem, that is, how to coherently relate the sola scriptura principle with the spiritualist domain of the principle of sola fides.

Within this framework, I will mainly refer to the principle of sola fides, since it is fundamental to the various philosophical receptions of Luther's thought. Regarding James, I take two essential ideas: self-surrender (one of the expressions more frequently used in Varieties), and the idea of the split between moral and religious experiences. In Luther's thought, the latter idea is clearly expressed in his distinction between justification through works and justification through faith. In other words, for Luther, doing a morally right act means nothing without faith. Faith comes first as God's gift, and as a consequence of having faith, we act correctly. Thus, there is, in my view, a clear distinction between religious experience and moral experience, since the latter presupposes the former.

One aspect of the named tension, which should be highlighted, relates to the modernity of Luther's thought: Does he set the outset of the modern era? Does his conception of religion belong to an authoritarian and ecclesiastical culture? (Troeltsch, Protestantism and Progress 10). The point I would like to emphasize is that there are grains of Luther's thought that could be interpreted as the seeds of modern and contemporary ideas. In the frame of this article, and having in mind James's conception of religion, I follow Troeltsch's insight of Protestantism and Progress, specifically his notion of Luther's "miracle of the idea." 
He needed for the personal life something purely personal. The means was therefore faith, sola fides, the affirmation, by the complete surrender of the soul to it, of that thought of God which has been made clear and intelligible to us in Christ. (192)

Troeltsch's conception is relevant to my paper for two reasons: first, he highlights as its most relevant feature the subjectivist element of Luther's thought; second, this subjectivist element can conduct us from Luther to James, that is, one can appreciate James's role in the reception of Luther's thought, as I will show below.

\section{Luther at the Core of Varieties}

James's conception of religion has several characteristics: first, its defense of the individual right to believe despite living in a time of secularization and growing atheism, particularly in academic circles; second, a pluralistic view on religion that involves the divine we believe in is based on our inclinations and preferences; third, like his contemporary Durkheim, James has drawn a kind of distinction between the sacred and the profane. ${ }^{13}$

Two aspects regarding what I call James's Lutheranism are of the utmost significance: first, the relevance of linking institutional and conceptual Lutheranism within James's thought; second, the direct influence of Luther's work on James's conception of religion. The first one will be considered in the next section. Thus, I will refer now to the influence of Luther on James's thought, specifically in Varieties. ${ }^{14}$

To put it directly, my hypothesis is that James's Lutheranism has two aspects: first, his clear distinction between morality and religion; and second, his distinction between faith and the content of faith. ${ }^{15}$ Regarding the first aspect, it can be unambiguously found in some passages of Varieties, for example, when James writes:

And here religion comes to our rescue and takes our fate into her hands. There is a state of mind, known to religious men, but to no others, in which the will to assert ourselves and hold our own has been displaced by a willingness to close our mouths and be as nothing in the floods and waterspouts of God. In this state of mind, what we most dreaded has become the habitation of our safety, and the hour of our moral death has turned into our spiritual birthday. (Varieties 46)

In this paragraph, James sharply distinguishes between religion and morals. But there is yet another element, namely that James's conception focuses not only on the idea that religion shows us a dimension that morality cannot 
reach, but also on religious experiences as being sometimes the result of an anti-moralistic method:

Under these circumstances the way to success, as vouched for by innumerable authentic personal narrations, is by an anti-moralistic method, by the "surrender" of which I spoke in my second lecture. Passivity, not activity; relaxation, not intentness, should be now the rule. (Varieties 95; emphasis added)

Two Jamesian elements can be pointed out in the previous paragraph: first, that morality never cures as religion does. In other words: even the best suffer for their weakness, and their vitality is like a shadow destined to die; second, that sometimes passivity — and not activity — is the key to solving our spiritual problems.

For my purposes, one point to highlight is that this passivity or quietism is explicitly connected with Luther's view on religion:

On the whole, one is struck by a psychological similarity between the mind-cure movement and the Lutheran and Wesleyan movements. To the believer in moralism and works, with his anxious query, "What shall I do to be saved?" Luther and Wesley replied: "You are saved now, if you would but believe it." (Varieties 94)

The scope of quietism has often been discussed in the literature about Luther and Lutheranism. ${ }^{16}$ In other words, has Luther promulgated a religion based only on an individual that "surrenders"? Regarding the individual's role, is it active only to the extent that he affirms or negates the call of grace? Different answers can be given to those questions. Usually, some courses of Lutheranism attempt to overcome the interpretation that attributes quietism to Luther's conception of religion, whose central exponent is Ernst Troeltsch. In terms of the German author:

[I]t does not become really intelligible until we see that his basic idea is that of grace as the gift of God, which objectively precedes and implies everything else, and that this divine grace is only obscured by human effort. Thus this stress upon free grace and human impotence leads Luther into an emphasis upon spiritual freedom and abandonment, which merges almost imperceptibly in a kind of Quietism. (Social Teaching 497)

Like Troeltsch, I think that Luther's conception of grace leads us to quietism. For my purposes, however, this is a marginal issue. The relevant focuses are two: first, that James interprets Luther à la Troeltsch, that is, attributing quietism to his conception of religion; second, that James uses 
this interpretation to ground his own view on religion. To understand both focuses, it is necessary to introduce some core issues of Varieties.

It is well known that three types of religious mentalities are presented in Varieties: the healthy, the sick soul, and the twice-born. Though radically different, these mentalities share a feature: they are intelligible only in terms of faith (or through justification by faith) and not of justification by works (in Lutheran terms).

For James, healthy souls are those that cannot perceive evil in the world. Moreover, in extreme cases, "in some individuals optimism may become quasi-pathological” (Varieties 75). What relationship does this bear with Lutheranism? They are not linked at a doctrinal level but through justification by faith, the mechanism proposed by Luther as fundamental. Put differently, the core of this mechanism is not action but our acceptance of God's grace. In James's terms: "It is but giving your little private convulsive self a rest, and finding that a greater Self is there" (Varieties 96). This giving up is overtly associated with Lutheran theology:

Give up the feeling of responsibility, let go your hold, resign the care of your destiny to higher powers, be genuinely indifferent as to what becomes of it all, and you will find not only that you gain a perfect inward relief, but often also, in addition, the particular goods you sincerely thought you were renouncing. This is the salvation through selfdespair, the dying to be truly born, of Lutheran theology, the passage into nothing of which Jacob Behmen writes. (Varieties 96)

Despite James's criticism of the shortcoming of healthy souls — which I will refer to below-they show us central features of human nature, that is, that one needs at least a dose of healthy character for survival. Moreover, in their religious aspect, these souls are fundamental in order to help us grasp the essence of religion, namely the faith-state, in James's words. He describes these features as follows:

The systematic cultivation of healthy-mindedness as a religious attitude is therefore consonant with important currents in human nature, and is anything but absurd. In fact, we all do cultivate it more or less, even when our professed theology should in consistency forbid it. We divert our attention from disease and death as much as we can; and the slaughter-houses and indecencies without end on which our life is founded are huddled out of sight and never mentioned, so that the world we recognize officially in literature and in society is a poetic fiction far handsomer and cleaner and better than the world that really is. (Varieties 80) 
This mentality is of fundamental importance for my argument, as it shows us one crucial issue: what is at stake is not the content of religious doctrines but the mechanism that allows religious experience to rise. This mechanism is based on the anti-moralistic, Lutheran method of the surrender of the self, which is exemplified in the following paragraph:

Martin Luther by no means belonged to the healthy-minded type in the radical sense in which we have discussed it, and he repudiated priestly absolution for sin. Yet in this matter of repentance he had some very healthy-minded ideas, due in the main to the largeness of his conception of God. (Varieties 110)

In other words, Luther's healthy mind does not relate to the doctrinaire level, but to his idea as to how the relationship between the individual and God works, that is, through the method of self-surrender. This necessarily entails the split between religious and moral experience, since the latter is grounded on the former.

Sick souls, on the other hand, perceive only evil in the world, a perception which is acutely felt, as pointed out by James:

Not the conception or intellectual perception of evil, but the grisly blood-freezing heart-palsying sensation of it close upon one, and no other conception or sensation able to live for a moment in its presence. (Varieties 135)

James sustains that this variety of religious experience is richer than the first one, in the sense that it allows us to comprehend more features of the world. Not only is this mentality presented as compatible with Luther's thought, but it is described by James by quoting Luther. Regarding the actuality of pessimism, the essential mark of this mentality, James writes:

The completest religions would therefore seem to be those in which the pessimistic elements are best developed. Buddhism, of course, and Christianity are the best known to us of these. They are essentially religions of deliverance: the man must die to an unreal life before he can be born into the real life. (Varieties 138)

But more specifically, James maintains that Protestant theology perfectly fits this kind of religious temperament:

It is needless to remind you once more of the admirable congruity of Protestant theology with the structure of the mind as shown in such experiences. In the extreme of melancholy the self that consciously is can do absolutely nothing. It is completely bankrupt and without resource, and 
no works it can accomplish will avail. Redemption from such subjective conditions must be a free gift or nothing, and grace through Christ's accomplished sacrifice is such a gift. (Varieties 198-99)

After this statement relating Protestant theology to sick souls, James quotes a long paragraph from Luther's Commentary on the Galatians, and he concludes with the following words:

That is, the more literally lost you are, the more literally you are the very being whom Christ's sacrifice has already saved. Nothing in Catholic theology, I imagine, has ever spoken to sick souls as straight as this message from Luther's personal experience. (Varieties 199-200)

From a theological perspective, the message in this paragraph is of remarkable importance. However, what I want to stress is not a theological but a methodological issue, namely that James shows us once more that religious experiences are grounded on an anti-moralistic method, that is, giving up of the self and trust in the divinity.

The last mentality presented by James in the Varieties is the twice-born. It is the most complete of all religious souls because they have seen both good and evil, that is, both sides of the abysm, and they have recovered through a process that James calls redemption:

The process is one of redemption, not of mere reversion to natural health, and the sufferer, when saved, is saved by what seems to him a second birth, a deeper kind of conscious being than he could enjoy before. (Varieties 131)

When James deals with these souls, he does not recur to Luther's works. However, from a logical point of view, he uses the same anti-moralistic Lutheran method to explain the way these souls should be conceived of:

It may come gradually, or it may occur abruptly; it may come through altered feelings or through altered powers of action; or it may come through new intellectual insights, or through experiences which we shall later have to designate as 'mystical.' However it comes, it brings a characteristic sort of relief; and never such extreme relief as when it is cast into the religious mould. Happiness! Happiness! Religion is only one of the ways in which men gain that gift. Easily, permanently, and successfully, it often transforms the most intolerable misery into the profoundest and most enduring happiness. (Varieties 146)

Thus, for twice-born as well as for healthy and sick souls, the most important feature is their ability to find a vital sense putting themselves aside and resting on a greater Self. 
I have just depicted the main features of James's religious mentalities and have shown how they share a crucial aspect, namely the split between morality and religion. But these mentalities share another essential feature: passivity. How does this explain the strenuousness that James sometimes attributes to moral agents and religious geniuses? I think that the analogy with Luther's view is enlightening. I have said above that, for Luther, moral experiences depend on basic and previous religious experiences. It is the same for James. There exists a religious passivity that could give way to strenuous moral actions. But passivity emerges first and, in James, by the anti-moralistic method of self-surrender. In other words: it is not through good works that one reaches God (or salvation) but through faith, and this can be the origin of a strenuous and fertile moral life. ${ }^{17}$

All religious experience is therefore radically different from moral experience. I have called this "James's Lutheranism" because the American philosopher grounded this conception on Luther's thought, particularly in a methodological way: the method of the surrender of the self.

Regarding belief and faith, James takes another fundamental step in Varieties, that is, he openly separates the intellectual content of faith from having faith. Unsurprisingly, James recurs to Luther to ground his position:

Faith that Christ has genuinely done his work was part of what Luther meant by faith, which so far is faith in a fact intellectually conceived of. But this is only a part of Luther's faith, the other part being far more vital. This other part is something not intellectual but immediate and intuitive, the assurance, namely that I, this individual I, just as I stand, without one plea, etc., am saved now and forever. (Varieties 200)

Faith has two connotations within James's work. In his melioristic account of religion, he conceives an active faith, that is, an energetic faith that helps to produce the desired object. This is crystal clear in The Will to Believe. However, in the mystical approach that I am taking in this paper, faith means something different, that is, to put aside ourselves and our supposed good and natural self-sufficiency to give place to the divinity. In other words, this is a faith related to the idea of self-surrender.

Meanwhile, Luther's conception of religion focuses-through the principle of sola fides - on individual experience as a primordial source of religion, but it conserves a very restrictive way to conceive the content of this experience through the principle of sola scriptura and the authority of the church. On the other hand, James distinguishes between faith and the content of faith. This step is central since it allows setting the core of religious experience within the individual. James's Lutheranism consists in taking one 
of Luther's basic insights, namely the fact of believing that one is saved as a fundamental ground of religion, putting aside doctrines and rites.

\section{In the Philosophical Path of Lutheranism: James on Religion}

Lutheranism unambiguously marked the development of Western philosophy, particularly in Germany. From Leibniz, Kant, and Schleiermacher to Feuerbach, Marx and Nietzsche, all German philosophy reacted to the work of the great reformer. As philosophical courses of Lutheranism, German philosophers refer mainly to the Lutheran principle of sola fides. One point to stress is how they reacted to Lutheranism, either by professing or rejecting it. I will leave aside those philosophers who rejected Lutheranism-the most radical being Marx and Nietzsche-and will briefly examine the philosopher who paradigmatically took the project of Lutheranism as his own: Hegel. One of the essential features of Hegelian philosophy is its emphasis on inwardness as a constitutive element of religion. For Hegel, Luther as well as Germany accurately understood the essence of the message, and therefore they considered inwardness to be the core of Christianity. In Hegel's words:

The time-honored and cherished sincerity of the German people is destined to effect this revolution out the honest truth and simplicity of its heart. While the rest of the world are urging their way to India, to America ... we find a simple Monk [Luther] looking for that specific embodiment of Deity which Christendom had formerly sought in an earthly sepulcher of stone, rather in the deeper abyss of the Absolute Ideality of all that is sensuous and external-in the Spirit and the Heart- the heart. (Philosophy of History 518-19) ${ }^{18}$

Consequently, a central feature of Hegel's appropriation of Luther's thought is his remark on the pre-eminence of inwardness and the principle of sola fides. But Hegel was a Lutheran who, in spite of firmly opposing the principle of sola scriptura and orthodox theology, defended the authority of the Lutheran Church. In his Philosophy of History, for example, he sustains that the Kingdom of the Spirit starts with Reformation and, more relevant to my purposes, that the Lutheran Church has the mission to instill universality and freedom into the world. Moreover, Hegel maintains that liberty and the Lutheran Church are two sides of the same coin:

[B] ut the heart-the emotional part of man's Spiritual nature-is recognized as that which can and ought to come into possession of the 
Truth; and this subjectivity is the common property of all mankind. Each has to accomplish the work of reconciliation in his own soul. . . . Thus that absolute inwardness of soul which pertains to religion itself, and Freedom in the Church are both secured. Subjectivity therefore makes the objective purport of Christianity, i.e. the doctrine of the Church, its own. (Philosophy of History 520)

The colossal magnitude of Hegel's philosophical project can be interpreted as an attempt to close the cycle that Luther had opened when undermining the authority of the Catholic Church. However, the vertiginous course of post-Hegelian European philosophy illustrates the great difficulties that such a program had: Lutheranism started to disintegrate, among other reasons, between Nietzsche's sharp darts and Kierkegaard's existentialism. Particularly Kierkegaard prefigures the destiny of Lutheranism in James's conception of religion. ${ }^{19}$ Thus, Hegel's endeavor to reconcile inwardness and the sola fides principle with the necessary universal authority of the Lutheran Church fails. However, his unrivaled portrait of Luther's profound transformation of religion remains, that is, the rejection of external authority and the subsequent primacy of individuals through the principle of sola fides and inwardness. Then, Hegel's best legacy is his conception of Luther as a religious genius.

Meanwhile, in America, the relationship between philosophy and religion followed a very different trail. Protestantism had been essentially Calvinist since Colonial times. Within this context, American Lutheranism had an unimportant philosophical impact and produced very limited theological developments, as sustained by the contemporary Lutheran theologian Martin Marty. ${ }^{20}$

In America, then, philosophy arises mainly from the reception of commonsense Scottish realism (Emerson being perhaps the most notable exception). Scottish realism was also changing its face to the extent that science (especially Darwinism) was undermining the theoretical framework of a biblical culture. It was within this context that James wrote on religion. In America and Germany, therefore, very different paths were followed that resulted in the marriage between Protestantism and philosophy: while the former consisted of a philosophical realism tied to Calvinism, the latter was an idealistic project grounded on the universal mission that Lutheranism had. ${ }^{21}$

Accordingly, within the American cultural scene, Scottish realism, Darwinism, and liberal theology formed the context where James's philosophy developed. ${ }^{22}$ Some interpreters infer that James's philosophical (and religious) views were shaped by them. However, to understand James's conception of 
religion as endorsing a kind of liberal theology is, in my view, deeply mistaken. ${ }^{23}$ One of the main targets of James's attack was the so-called liberal Christianity or liberal Protestantism:

The advance of liberalism, so-called, in Christianity, during the past fifty years, may fairly be called a victory of healthy-mindedness within the church over the morbidness with which the old hell-fire theology was more harmoniously related. We have now whole congregations whose preachers, far from magnifying our consciousness of sin, seem devoted rather to making little of it. They ignore, or even deny, eternal punishment, and insist on the dignity rather than on the depravity of man. They look at the continual preoccupation of the old-fashioned Christian with the salvation of his soul as something sickly and reprehensible rather than admirable; and a sanguine and "muscular" attitude, which to our forefathers would have seemed purely heathen, has become in their eyes an ideal element of Christian character. (Varieties 91)

Although, in the previous paragraph, James is not judging but only describing the situation of Protestantism, he is very critical of the idea of religion being absorbed into morality, that is, he does not agree with the Pelagian ethos that Protestantism had within the second part of the nineteenth century because it does not take account of the morbid side of religious experiences.

Meanwhile, Darwinism - which is another source usually mentioned by James-is useless within this context because science and religion address dissimilar human needs (see note 13). Finally, Scottish realism (the last constituent of the cultural scene in nineteenth-century America that I will refer to) is worthless to understand sick souls, and it was early rejected by James because of its atomism. ${ }^{24}$

Within this common framework, I think there is an insightful way to grasp James's conception of religion from a different perspective. In other words, despite the enduring attacks carried out by James against Hegel (and Hegelianism), they share a fundamental view: Luther is a religious genius who has transformed our conception of what a religious experience is, on the one hand; and this transformation is grounded on the idea of inwardness and the principle of sola fides, on the other hand.

Consequently, what I call Hegel's best legacy-to conceive Lutheran religion as accurately finding the essence of Christianity in interiority-finds its highest radicalism in James's view on religion, since both depict Luther as the most important modern religious genius. James is as explicit as Hegel concerning this issue: 
Just as romantic love seems a comparatively recent literary invention, so these experiences seem to have played no great part before Luther's time; and the best way to indicate their character will possibly be to draw a contrast between the inner life of ourselves and of the ancient Greeks and Romans." ("Reason and Faith" 200; emphasis added) ${ }^{25}$

From the essential words of this paragraph, that is, the inner life of ourselves, it can be inferred that James thinks of modern individuals-like himself-as following the path opened by Luther. Within this course, Hegel was halfway between sola fides and the authority of the Lutheran Church. James, on the other hand, unfolds the decisive consummation of Luther's individualism:

The pivot round which the religious life, as we have traced it, revolves, is the interest of the individual in his private personal destiny. Religion, in short, is a monumental chapter in the history of human egotism. The gods believed in — whether by crude savages or by men disciplined intellectually_agree with each other in recognizing personal calls. Religious thought is carried on in terms of personality, this being, in the world of religion, the one fundamental fact. Today, quite as much as at any previous age, the religious individual tells you that the divine meets him on the basis of his personal concerns. (Varieties 491)

However, Luther's religious genius consists not only in giving rise to the individualization of religion but — as insightfully pointed out by James-in describing a very particular kind of religious experience:

Luther was the first moralist who broke with any effectiveness through the crust of all this naturalistic self-sufficiency, thinking (and possibly he was right) that Saint Paul had done it already. Religious experience of the Lutheran type brings all our naturalistic standards to bankruptcy. You are strong only by being weak, it shows. (Pluralistic Universe 137)

Looking at Varieties through this paragraph of A Pluralistic Universe, one can grasp Luther's awesome relevance to focus on a fundamental current nucleus of religion: the morbid side of existence that James calls "the sick souls." This invention-in terms of James_-not only makes Luther our contemporary, but it allows us to infer that he is not only a common religious genius, that is, a religious genius as George Fox, St. Teresa, or St. Ignatius Loyola. In other words, Luther is a religious genius who originated the contemporary way to conceive religion, for two reasons: on the one hand, he was the first to buck the naturalistic trend in religion; on the other hand, since 
Luther's life and work, we have had a radically new approach to religious experiences, that is, we have to take sick souls seriously.

Summing up, religious inwardness shows us a philosophical course that can be drawn from Luther to Hegel and James. Hegel, however, is still trapped in the Lutheran - universalist - conception of church, while James puts aside rituals and doctrines as central elements of religion and focuses on feelings, acts, and experiences. This Jamesian move let us conceive contemporary creeds as contingent expressions of religious experiences and, for this reason, more suitable for pluralistic societies.

Thus, if we conceive the sola fides principle as the fundamental legacy of Lutheranism, James could be interpreted as a Lutheran who gave the coup de grâce to the last objective remains of orthodox Lutheranism: the universal authority of the Church. This could be seen as a decisive step in the history of philosophical receptions of Lutheranism. Consequently, James asserts a distilled Lutheranism coherently grounded only on the principle of sola fides without any connection with the objective aspect of Luther's thought, that is, by taking seriously the role of the individual before the divinity, James becomes one of the most radical representatives of the Lutheran principle of sola fides. If one examines philosophical receptions of Luther, the Jamesian is one of the first to really leave the individual alone before the divinity, that is, to explicitly avoid any kind of necessary mediation. In James's words:

$[T]$ he individual transacts the business by himself alone, and the ecclesiastical organization, with its priests and sacraments and other gobetweens, sinks to an altogether secondary place. The relation goes direct from heart to heart, from soul to soul, between man and his maker. (Varieties 29)

\section{Conclusion}

Not only did Luther's conception of religion change religious thought forever, but it also had an enormous impact on Western philosophy. ${ }^{26}$ For philosophy, this Lutheran impact is centrally owed to the principle of sola fides, as I have attempted to show. German philosophy, particularly, is impossible to understand without a Lutheran background. However, I think it was not in Germany but in America where the philosophical course of Lutheranism reached its maximal radicalism and coherence. It was William James who, putting aside doctrines and rites as the elementary forms of religion, established the central importance of the principle of sola fides.

In the present article, I have defended three theses about James's conception of religion: first, that it was markedly influenced by Luther's thought; 
second, that it presents a dual Lutheranism (split between religion and morality grounded on the method of self-surrender/distinction between the content of faith and having faith); and third, that it represents one of the most radical interpretations of Luther's thought, that is, the primacy of Luther's conception of faith against his idea of church and sola scriptura.

These theses have a different scope. If I am right about the first one, we should consider what consequences James's dual Lutheranism implies: the split between religion and morality is nothing but to give a new form to the principle of the great reformer, and only faith and grace capture the essence of religion. Meanwhile, the distinction between faith and the content of faith gives James's Lutheranism its particularity, namely the radicalization of Luther's best intuition that only faith captures the essence of religion, while disregarding its articulation in creeds as only a contingent aspect. This is the cardinal importance of James if we consider his work as a philosophical course of Lutheranism. In other words, the distinction between faith and the content of faith implies the definitive victory of the principle of sola fides against the principle of sola scriptura. Thus, through James's work, the nails of Wittenberg reverberate in the streets of New England.

\section{NOTES}

I finished this paper during my visit to the Department of Philosophy at Texas A\&M University (College Station) (December 2013-March 2014) where I was supported with a fellowship from CONICET (Argentina). I thank my host, Gregory Pappas, and especially Professor John McDermott for useful discussion on the draft of this article. The language was revised by Rita Karina Plasencia.

1. Quoted in Hockenbery Dragseth v.

2. I do not attempt to deal here with James's own religious experiences and needs. My purpose is to examine James's Varieties from a conceptual point of view and to establish its connections with Luther and Lutheranism.

3. James explicitly identifies himself with Protestant traditions in several works. In The Will to Believe (16), for example, he says:

It is evident that unless there be some pre-existing tendency to believe in masses and holy water, the opinion offered to the will by Pascal is not a living option. Certainly, no Turk ever took to masses and holy water on its account; and even to us Protestants these means of salvation seem such foregone impossibilities that Pascal's logic, invoked for them specifically, leaves us unmoved.

See also Varieties 265.

4. In Hollinger's words:

Such cases "in the annals of Catholic saintship," he [James] says explicitly, "make us rub our Protestant eyes." There is no question who the "we" or the "us" is whenever James invokes these portentous pronouns. What casts James's treatment of Fox and other canonical Protestants into bold relief, then, is not so much his fleeting use of 
Muslim and Jewish cases but the sustained treatment he gives to Catholics. One can easily get the impression that Varieties is a non-individual harvest of the most intense spiritual moments of all the major religions, especially of Christianity, embracing Catholic as well as Protestant variations. But no. Varieties is constructed to foreground certain religious sensibilities and not others, and to present the core of religion in general as having been most attractively manifest in exactly the cultural tradition to which James's listeners and readers were directly heir. (13)

5. Ralph Barton Perry (257), for example, writes: "But while James identifies religion with certain specific experiences revealed, he did not identify religion with any particular creed." A similar interpretation can be found in Levinson (21).

6. This is the interpretation of some important scholars, too. Hollinger (11), for example, sustains that:

James's ostensibly species-wide account of religious experience is deeply Protestant in structure, tone, and implicit theology. Even the categories of religious experience around which Varieties is organized, and the order in which James describes them, have this quality. As theologian Reinhold Niebuhr and others have pointed out, James, by moving from "healthy-mindedness" to the "sick soul" to the "divided self" to "conversion" and then to "saintliness," follows the prescribed sequence of the evangelical Protestant conversion narratives.

Meanwhile, Julius Rubin (18) points out the Protestant features of James's religious thought: "Although ostensibly a general work on religion, James's essays actually explored Protestantism, in particular, the forms of religious experience found within early nineteenth-century New Englander spiritual biographies."

7. Also Gale (256) and Myers (472) sustain that the core of Varieties rests on the notion of self-surrender.

8. Other paragraphs of Spohn's article show his deep understanding of James's conception of religion: "James interpreted his experience of depression and deliverance in this pattern, even though it evoked a faith that was not necessarily Christian. He acknowledged that Protestant theology, particularly Luther's, has 'admirable congruity' with his account of the transformation of 'the sick soul'" (37). Moreover, Spohn stresses (33) the centrality of Christianity for James's thought: "The central symbol of the Christian tradition, the death and resurrection of Jesus Christ, as interpreted through Evangelical Christianity, lurks behind the language of a theory that claims to transcend traditional symbols and doctrines." Finally, Spohn identifies (33) a key element underlying James's approach to religion: "However anonymously, James stands within the tradition of Augustinian piety that dominates American religion."

9. Hinlicky (25) writes:

Another, more specific clue to the theological dead-end to which the method of "enthusiasm" comes is the schizophrenic treatment accorded to Luther in Varieties. Luther appears in these pages as an example of healthy "mind cure" (Varieties 107-08). But this supposed mile marker on modern culture's road to religious inwardness could also be classified with the sick soul's crisis of "self-surrender" (Varieties 211), as James describes the sick old man Luther who "looked back on life as if it were an absolute failure" (Varieties 137).

Although I disagree with Hinlicky's view that James's dealing with Luther in Varieties was schizophrenic, I acknowledge that he has insightfully remarked on Luther's influ- 
ence on James's thought. I really appreciate the anonymous reviewers' observation that I should include Hinlicky's book in my article.

10. I am fully aware that there are several possible perspectives on James's view of religion and that they depend on what one considers to be the core of his thought. Those forms have been labeled Prometheanism (McDermott, Introduction xix) and mysticism. The first is clearly exemplified in Richard Gale's interpretation:

When James was in his healthy Promethean frame of mind he tingled all over at the thought that we are engaged in a Texas Death Match with evil, without any assurance of possibility of victory. This possibility forms the basis of his religion of meliorism. But there is a morbid side to James's nature, a really morbid side, that "can't get no satisfaction" from the sort of religion that his pragmatism legitimates. In order to "help him make it through the night" he needs a mystically based religion, which gives him a sense of absolute safety and peace that comes through union with an encompassing spiritual reality. (16)

An opposing way to understand James's conception of religion can be seen in Michael Slater ("Metaphysical Intimacy" 122):

The third and final criterion, moral helpfulness, denotes the values of a belief or experience for the moral life, and in the context of James's studies of religious experience this may very well be the most important of the three. In particular, James thinks that it is the good dispositions (VRE 24-26) produced by religious and mystical experience which provide us with the best indicators of their truth, though such dispositions are valuable in their own right on moral grounds.

Also, James's Pragmatism (144) helps to support Slater's interpretation. Two different conceptions of faith are at stake here: James's mystical aspect is grounded on a passive concept of faith; meanwhile, in his Promethean facet, faith is an active-or strenuous - human endeavor linked with morals. What role does Varieties play within James's thought? I think there is a tension in the book between the melioristic and the mystical sides. The latter-essentially through the idea of self-surrender-is fundamental to what I conceive as the core of the book, that is, the description of the three religious mentalities. Meanwhile, the former side plays a central role in the conclusion through Leuba's notion of use (Varieties 399). It could therefore be thought that in Varieties, the tension between the melioristic and mystical sides of James's philosophy of religion finds its utmost expression. I ground my interpretation on the mystical side of James's conception of religion.

11. Gerhard Ebeling (21) has clearly drawn this distinction between theological orthodoxy and philosophical re-creations of Luther's thought:

The period of Protestant orthodoxy modified the view of him [Luther] as a prophet, emphasizing more his restoration of pure doctrine. A section de vocatione Lutheri actually occurs as a part of dogmatic theology in some works of early Protestant orthodoxy. Pietism made a similar appeal to Luther, but it distinguished between Luther in his earlier and later years. A contrast was drawn between the period when he was supposed to have become embittered by his opposition to the enthusiastic sects and by disputes within Protestantism, - if not actually inclined to a certain extent to return to Catholicism - and the early period when the gospel of repentance and grace, still pure and close to the devotional literature of German mysticism which was so highly regarded by pietism, remained clearly visible. The Enlightenment 
also saw Luther as its pattern and example, emphasizing the freedom of conscience which he had made possible. . . . [T] he dominant view, inspired by denominational and idealistic motives, regarded Luther as the forerunner of the modern period.

12. Several philosophers have emphasized that the sola fides principle should prevail over the sola scriptura principle (Leibniz, Lessing, and Kant, among others). A detailed examination of this issue can be seen in Ginzo Fernández.

13. I have written an article relating James and Durkheim: see Viale, "Sacred/Profane."

14. Although references to Luther are not important within The Correspondence of William James, and they are made mainly in an informal and not conceptual way, there is a letter to Leuba dated 1904 (396), where James writes the following:

Religious men largely agree that this sense has been that of their "best" moments, best not only when passing, but when looked back upon. The notion of it has leaked into mankind from their authority, the rest of us are imitative, just as we are of scientific men's opinions. We live by Luther's just as we do by Newton's suggestions, and find ourselves helped by both.

I will argue, therefore, that James conceives of Luther as one of the most paradigmatic models of religious geniuses.

15. Although I ground my argument on Varieties, it is important to highlight that as early as 1884 , James entertains a clear distinction between morality and religion. Analyzing, for example, The Literary Remains by Henry James, Sr., he endorses the following paragraph: "It shows the depth of Mr. James's religious insight that he first and last and always made moralism the target of his hottest attack, and pitted religion and it against each other as enemies, of whom one must die utterly, if the other is to live in genuine form. The accord of moralism and religion is superficial, their discord radical' (James, Essays in Religion and Morality 62-63; emphasis added). James Pawelski (22) stresses this difference too:

James's distinction between moralism and religion can be succinctly described as referring to two different ways individuals can accept the universe. James argues that, although both moralists and religionists have a finite place in the order of things, they respond to their finitude in different ways. Moralists accept it only because they must. Their muscles are tensed in struggle against the order of things. Religionists, on the other hand, accept, welcome, and even love the universe and their finite place in it. Moralists respond willfully: religionist, passionately. Paradoxically, however, the result of these responses is that moralists are on the defensive and find it harder to act in the world, whereas religionists are free to be aggressive in their active relations with the world.

16. Reinhold Niebuhr (187-88), for example, has accused Luther of quietism: "Sometimes he lapses into mystical doctrines of passivity or combines quietism with a legalistic conception or the imputation of righteousness. 'Without works' degenerates into 'without action' in some of his strictures against the 'righteousness of works."' A critical analysis of this position can be seen in Brent W. Sockness.

17. A paragraph by Douglas Anderson (9) could be interpreted in a similar way:

The self-surrender or submission, ironically, leads to a rebirth. The converted soul feels empowered in ways that she or he had not previously experienced. ... [T] he difference from the free power and agency felt by the healthy-minded is that the personal power now has a clearly self-transcendent source: a living ideal or power. 
The converted soul finds herself or himself living in a wider life where things can be seen more clearly.

18. Hegel (519) follows: "Luther's simple doctrine is that the specific embodiment of Deity - infinite subjectivity, that is true spirituality, Christ—is in no way present and actual in an outward form, but as essentially spiritual is obtained only in being reconciled to God-in faith and spiritual enjoyment."

19. I owe clarification of this point to Professor John McDermott.

20. Marty (79) clearly states that action was more necessary than theoretical development:

The Evangelical empire and the people in it needed guidance and interpretation. To think of this activity as "doing theology" seems confusing to many people. In their model, theology demands great minds. It is difficult to make a case for many religious geniuses on the American scene between Jonathan Edwards and Josiah Royce, William James, or Walter Rauschenbusch over a century later. Among the churchmen, perhaps Horace Bushnell alone is much read a century later. At the fringes of religious life an occasional spirit like Ralph Waldo Emerson attracted notice.

21. Hegel's reception in America (particularly among St. Louis Hegelians) pointed out the relevance of religion, but generally the Lutheran framework of the German philosopher was disregarded. Concerning this issue, Henry Pochmann (26), for example, writes the following:

When the St. Louis Movement began, the difference between what Parker called the transient and the permanent in religion had not been so sharply drawn nor were they so clearly understood as they are today. The drawing of this distinction between religion itself on the one hand and the expression of religion in doctrines and rites, or the application of religion through institutions, on the other, is one of the great achievements of the nineteenth century.

22. Bruce Kuklick (10) points out this link:

If we consider all American religious movements of the nineteenth century, the views of the numerically unimportant Unitarians were such that many Christians would not have considered them co-religionists. Nonetheless, both the Unitarians and the other denominations that spoke for the socioeconomic elites in various parts of the country found a theoretical rationale in the same philosophy: Scottish realism. This school of thought held great interest for those in American Protestantism who were concerned with philosophical problems of religion.

23. This point was very clearly made by Barton Perry (259): "From James's emphasis upon uniqueness of the religious experience, and its specific factual implications, arose his paradoxical relation to contemporary Christianity. Religion of the sort in which he was interested was closer to the simply piety of the evangelical sects than to that of modern religious liberalism." However, to understand James's conception of religion as belonging to liberal Protestantism is a very common mistake within the literature. Examples of this misunderstanding can be found in the works of Hollinger; Porterfield (140-41); and Dorrien (224-25); among others.

24. I also owe clarification of this point to Professor McDermott.

25. This article was based on a William James's conference: "In 1906, while lecturing at Leland Stanford, William James accepted an invitation to contribute to a discussion 
of "Reason and Faith" at a dinner of the Pacific Coast Unitarian Club in San Francisco on February 5th. What follows is a summary of what he said which he himself prepared to be printed in the proceedings of the meeting" (Henry James, qtd. in William James, "Reason and Faith").

26. Particularly in Germany. Habermas said (68) that "philosophy in Germany lives so thoroughly out of the Protestant spirit that Catholics practically have to become Protestant in order to do philosophy."

\section{REFERENCES}

Anderson, Douglas R. "Respectability and the Wild Beasts of the Philosophical Desert: The Heart of James's Varieties.” Journal of Speculative Philosophy 17.1 (2003): 1-13.

Croce, Paul. "Mankind's Own Providence: From Swedenborgian Philosophy of Use to William James's Pragmatism.” Transactions of the Charles Peirce Society 43.3 (2007): 490-508.

Dorrien, Gary. The Making of American Liberal Theology, Idealism, Realism, and Modernity: 1900-1950. Louisville: Westminster John Knox P, 2003.

Ebeling, Gerhard. Luther: An Introduction to His Thought. Trans. R. A. Wilson. Minneapolis: Fortress P, 2007.

Gale, Richard M.. The Divided Self of William James. Cambridge: Cambridge UP, 1999.

Ginzo Fernández, Arsenio. Protestantismo y filosofía. La recepción de la Reforma en la filosofía alemana. Madrid: Universidad de Alcalá, 2000.

Habegger, Alfred. The Father: A Life of Henry James, Sr. New York: Farrar, Straus and Giroux, 1994.

Habermas, Jürgen. Philosophical-Political Profiles. Cambridge: MIT P, 1983.

Hegel, Georg. Philosophy of History. Trans. J. Sibree. New York: American Dome Library, 1902.

Hinlicky, Paul R. Luther and the Beloved Community. Grand Rapids: Eerdmans, 2010.

Hockenbery Dragseth, Jennifer. The Devil's Whore: Reason and Philosophy in the Lutheran Tradition. Studies in Lutheran History and Theology. Minneapolis: Fortress P, 2011.

Hollinger, David. “'Damned for God's Glory': William James and the Scientific Vindication of Protestant Culture.” William James and a Science of Religions: Reexperiencing The Varieties of Religious Experience. Ed. Wayne Proudfoot. New York: Columbia UP, 2004. 9-30

James, William. The Correspondence of William James. Ed. Ignas K. Skrupskelis and Elizabeth M. Berkeley. Charlottesville: UP of Virginia, 2002.

- Essays in Religion and Morality. The Works of William James. Ed. Frederick Burkhardt, Fredson Bowers, and Ignas K. Skrupskelis. Cambridge: Harvard UP, 1982.

—. A Pluralistic Universe. The Works of William James. Ed. Frederick Burkhardt and Ignas K. Skrupskelis. Cambridge: Harvard UP, 1979.

—. Pragmatism. The Works of William James. Ed. Frederick Burkhardt and Fredson Bowers. Cambridge: Harvard UP, 1975.

—. "Reason and Faith." Journal of Philosophy 24.8 (1927): 197-201.

- Some Problems of Philosophy. The Works of William James. Ed. Frederick Burkhardt, Fredson Bowers, and Ignas K. Skrupskelis. Cambridge: Harvard UP, 1979. . The Varieties of Religious Experience. The Works of William James. Ed. Frederick Burkhardt. Cambridge: Harvard UP, 1985. 
. The Will to Believe and Other Essays in Popular Philosophy. The Works of William James. Ed. Frederick Burkhardt, Fredson Bowers, and Ignas K. Skrupskelis. Cambridge: Harvard UP, 1979.

Kuklick, Bruce. The Rise of American Philosophy: Cambridge, Massachusetts, 18601930. New Haven: Yale UP, 1977.

Levinson, Henry Samuel. The Religious Investigations of William James. Chapel Hill: U of North Carolina P, 1981.

Lundin, Roger. "Natural Experience: Emerson, Protestantism, and the Emergence of Pragmatism." Religion \& Literature 32.3 (2000): 23-67.

Luther, Martin. The Babylonian Captivity of the Church. Luther's Works. Vol. 46. Ed. Helmut T. Lehmann and Abdel Ross Wentz, Trans. A. T. W. Steinhäuser. Philadelphia: Muhlenberg P, 1959.

- The Good Works. Luther's Works. Vol. 44. Ed. Helmut T. Lehmann and James Atkinson, Trans. W. A. Lambert. Philadelphia: Fortress P, 1966.

—_. 95 Theses. Luther's Works. Vol. 31. Ed. Helmut T. Lehmann and Harold J. Grimm, Trans. Charles M. Jacobs. Philadelphia: Concordia Publishing House and Muhlenberg P, 1957.

- To the Christian Nobility of the German Nation. Luther's Works. Vol. 44. Ed. Helmut T. Lehmann and James Atkinson, Trans. Charles M. Jacobs. Philadelphia: Fortress P, 1966.

- Small Catechism. Concordia: The Lutheran Confessions-A Reader's Edition of the Book of Concord. Ed. Paul T Mcain. 2nd ed. 1530. St. Louis: Concordia, 2007.

Marty, Martin E. Righteous Empire: The Protestant Experience in America. New York: Dial P, 1970.

McDermott, John J. Introduction. The Writings of William James. Chicago: U of Chicago P, 1977. xiii-xliv

- Streams of Experience: Reflections on the History and Philosophy of American Culture. Amherst: U of Massachusetts P, 1987.

McGrath, Alister E. Reformation Thought. Oxford: Blackwell, 1995.

Myers, Gerald. William James: His Life and Thought. New Haven: Yale UP, 1986.

Niebuhr, Reinhold. The Nature and Destiny of Man. Vol. 2: Human Destiny. New York: Scribner's, 1943.

Pawelski, James O. The Dynamic Individualism of William James. Albany: State U of New York P, 2007.

Perry, Ralph Barton. The Thought and Character of William James. Cambridge: Harvard UP, 1967.

Pochmann, Henry A. New England Transcendentalism and St. Louis Hegelianism. New York: Haskell House, 1949.

Porterfield, Amanda. The Protestant Experience in America. Westport: Greenwood P, 2006.

Rubin, Julius H. Religious Melancholy and Protestant Experience in America. New York: Oxford UP, 1994.

Slater, Michael R. "Ethical Naturalism and Religious Belief in 'The Moral Philosopher and the Moral Life.” William James Studies 2 (2007). http://williamjamesstudies.org/ 2.1/slater.html.

. "Metaphysical Intimacy and the Moral Life: The Ethical Project of The Varieties of Religious Experience.” Transactions of the Charles Peirce Society 43.1 (2007): 116-53.

Sockness, Brent. "Luther's Two Kingdoms Revisited: A Response to Reinhold Niebuhr's Criticism of Luther." Journal of Religious Ethics 20.1 (1992): 93-110. 
Spohn, William C. "William James on Religious Experience: An Elitist Account?” American Journal of Theology \& Philosophy 15.1 (1994): 27-41.

Troeltsch, Ernst. Protestantism and Progress: A Historical Study of the Relation of Protestantism to the Modern World. London: Williams \& Norgate, 1912.

The Social Teaching of the Christian Churches. New York: Macmillan, 1931.

Viale, Claudio Marcelo. "Sacred/Profane-The Durkheimian Aspect of William James's Philosophy of Religion.” Pragmatism Today 3.1 (2012): 144-56.

Zehnder, David J. "The Hermeneutical Keys to William James's Philosophy of Religion: Protestant Impulses, Vital Belief.” Forum Philosophicum 15.2 (2010): 301-17. 